\title{
Helical Flagellation in Centipeda periodontii, a Gram-negative, Anaerobic Bacillus from Periodontitis Lesions
}

\author{
By B. M. MALES, ${ }^{*} \dagger$ P. BERTHOLD, P. A. DOUGHERTY AND \\ M. A. LISTGARTEN \\ University of Pennsylvania School of Dental Medicine and Center for Oral Health Research, \\ 4001 Spruce Street, Philadelphia, PA 19104, USA
}

(Received 25 April 1983; revised 12 August 1983)

\begin{abstract}
The insertion pattern of flagellation of Centipeda periodontii was determined from electron micrographs of negatively stained cells treated with various detergents to remove their outer cell wall layer(s) selectively. The best results were obtained with $0 \cdot 2 \%$ sodium dodecyl sulphate and a treatment time of 1-2 min. Detergent-treated cells displayed a unique helical pattern of flagellation which we designate as helicotrichous (Gk $\mathrm{n}$. helix, helix $+\mathrm{Gk} \mathrm{n}$. thrix, hair). Flagella originated from an electron-dense region approximately $180 \mathrm{~nm}$ wide, which spiralled around the cell body. The length of the insertion path averaged $2.6 \mu \mathrm{m}$ per $360^{\circ}$ turn; its periodicity was $2.5 \mu \mathrm{m}$. An average of 19 flagella were inserted per $1 \mu \mathrm{m}$ length of the electrondense region. The effects of cell division and branching on flagellation were also examined.
\end{abstract}

\section{INTRODUCTION}

Motile bacteria, other than spirochaetes, are divided into three groups based on their pattern of flagellation: peritrichous, polar and lateral. The latter category includes Selenomonas species which have a tuft of flagella on their concave side (Kingsley \& Hoeniger, 1973) and Pectinatus cerevisiiphilus, which has a comb-like arrangement of flagella (Lee et al., 1978). The arrangement of flagella on a recently isolated oral bacterium, Centipeda periodontii, suggests an additional pattern of flagellation (Lai et al., 1981 $a$, 1983). These bacteria were initially described as Gram-negative, anaerobic bacilli which are motile and slightly serpentine in shape (Lai et al., $1981 a$ ). The most striking feature of the isolates was their 'centipede-like' appearance when viewed by dark-field microscopy due to many sets of flagellar bundles which extend from both sides of the cell body. Electron microscopic studies of negatively stained specimens verified these observations and in some cases suggested an unusual arrangement of the flagella (Lai et al., 1983).

To elucidate further the specific arrangement of flagellar insertions, we undertook an electron microscopic study of several isolates which had been subjected to gentle lytic treatment to remove their outer cell wall layer(s) without gross disruption of the cell structure. Cells thus treated will be referred to as being 'stripped' of their outer cell wall layer(s). This report describes the lytic procedure and demonstrates the occurrence of a heretofore undescribed pattern of flagellation.

\section{METHODS}

Bacterial strains. The isolates were recovered from subgingival plaque from patients with either chronic or juvenile periodontitis (Lai et al., 1983). The following strains of Centipeda periodontii were used: LL2383 (ATCC 35019, the type strain), LL2441 and LL2467.

$\dagger$ Present address: Erie County Laboratory \& Medical Center, Division of Clinical Microbiology and Immunology, 462 Grider Street. Buffalo, NY 14215, USA.

Ahbretiation: SDC, sodium deoxycholate. 
Preparation of lysed cell specimens. Each strain was grown for 24 or $48 \mathrm{~h}$ in $10 \mathrm{ml}$ of brain heart infusion supplemented (BHIS) (Holdeman et al., 1977) in an anaerobic chamber with an atmosphere of $\mathrm{N}_{2} / \mathrm{CO}_{2} / \mathrm{H}_{2}$ $(80: 10: 10$, by vol. $)$ at $35^{\circ} \mathrm{C}$. Cells were harvested by gentle centrifugation $(3000 \mathrm{~g}, 10 \mathrm{~min})$ and resuspended in a few drops of sterile saline. A drop of the bacterial suspension was placed on a one-hole Formvar-carbon coated nickel grid and excess fluid was removed by blotting. The specimens were immediately covered with one drop of a sterile solution of $0.2 \%(\mathrm{w} / \mathrm{v})$ sodium dodecyl sulphate (SDS) (Bayer \& Anderson, 1965) or with $1 \%$ ( $/ \mathrm{v} / \mathrm{v}$ ) sodium deoxycholate (SDC) (Hill, 1967; Hougen \& Birch-Andersen, 1971) for various periods (0.5, 1, 2, or 4 min). The grids were blotted, stained with a single drop of $2 \%(\mathrm{w} / \mathrm{v})$ phosphotungstic acid $(\mathrm{pH} 7.4)$ for $1.5 \mathrm{~min}$, blotted again and air-dried.

Cells treated with physiological saline were used as controls.

Electron microscopy. Specimens were examined in a Philips EM 300 operated at 60 or $80 \mathrm{kV}$. Approximately 200 micrographs from 60 specimens were studied.

\section{RESULTS AND DISCUSSION}

\section{Cell lysis by detergents}

Consistent results were obtained for each isolate that was treated with SDS. The degree of lysis was time dependent. Treatment times of 1 and 2 min yielded the greatest number of stripped cells without gross disruption of cell shape or loss of external appendages, i.e. flagella (Fig. 1). The control specimens, which were not detergent-treated, showed no such loss (Fig. 2). A relatively smooth cell surface remained after detergent treatment, with the sites of flagellar insertion clearly visible. Almost no stripped cells were seen when the period of SDS treatment was limited to $30 \mathrm{~s}$. A treatment time of $4 \mathrm{~min}$ resulted in fragmentation of flagella, with breakage at points proximal to the hook region (Fig. $3 a$ ). Greater numbers of disintegrated cells were also seen. The remaining debris frequently consisted of an intact flagellar insertion region (Fig. $3 b$ ).

Use of SDC was not as effective in producing stripped cells. A large proportion of cells treated with SDC for periods of 1-4 min retained most of their flagella as intact structures and disclosed cell surfaces with the outer layer(s) only partly removed. In such preparations, regions of flagellar insertions on these cells were correspondingly less well defined (Fig. 4).

\section{Flagellar insertion region}

A narrow electron-dense zone, into which most of the individual flagella were inserted, traversed the length of SDS-treated cells (Fig. 1). We have interpreted its 'zigzag' pattern as a two-dimensional view of a three-dimensional, helical path visible through the treated cell. Along this narrow path many overlapping flagella originated and coalesced into flagellar bundles alternately arranged along both cell sides, near concave regions of the cell curvature (Fig. 1).

Bacterial flagella are composed of a filament, hook and basal body. The latter structure is embedded in the cell wall. A model for the basal body complex among Gram-negative organisms, such as Escherichia coli, has been proposed. The structure is $27 \mathrm{~nm}$ in length and consists of four rings in pairs, $22.5 \mathrm{~nm}$ in diameter, surrounding a narrow rod. The innermost ring is anchored in the cytoplasmic membrane (DePamphilis \& Adler, 1971 $a, b$ ). Examination of stripped cells of Centipeda periodontii occasionally showed intact expelled flagella lying adjacent to the cell body. The dimensions of the attached basal bodies were similar to those described by DePamphilis \& Adler (1971 a) (unpublished observations). It is unlikely that the basal body complex seen in our specimens is responsible for formation of the electron-dense zone (described below). The observance of an electron-dense insertion path suggests the presence of an additional substance or structure within the cell. A number of structures have been described in polar and laterally flagellate bacteria which are associated with regions of flagellar insertion. They include membranous structures (Murray \& Birch-Andersen, 1963; Ritchie et al., 1966; Cohen-Bazire \& London, 1967; Remsen et al., 1968; Vaituzis \& Doetsch, 1969; Kingsley \& Hoeniger, 1973; Lai et al., 1981 b), polar discs and plates (Remsen et al., 1968) and concentric membrane rings (Coulton \& Murray, 1978). These structures are thought to contain flagellum-synthesizing machinery or to be necessary for anchorage of the flagella. Such structures might confer additional rigidity (and density) to the region from which flagella 

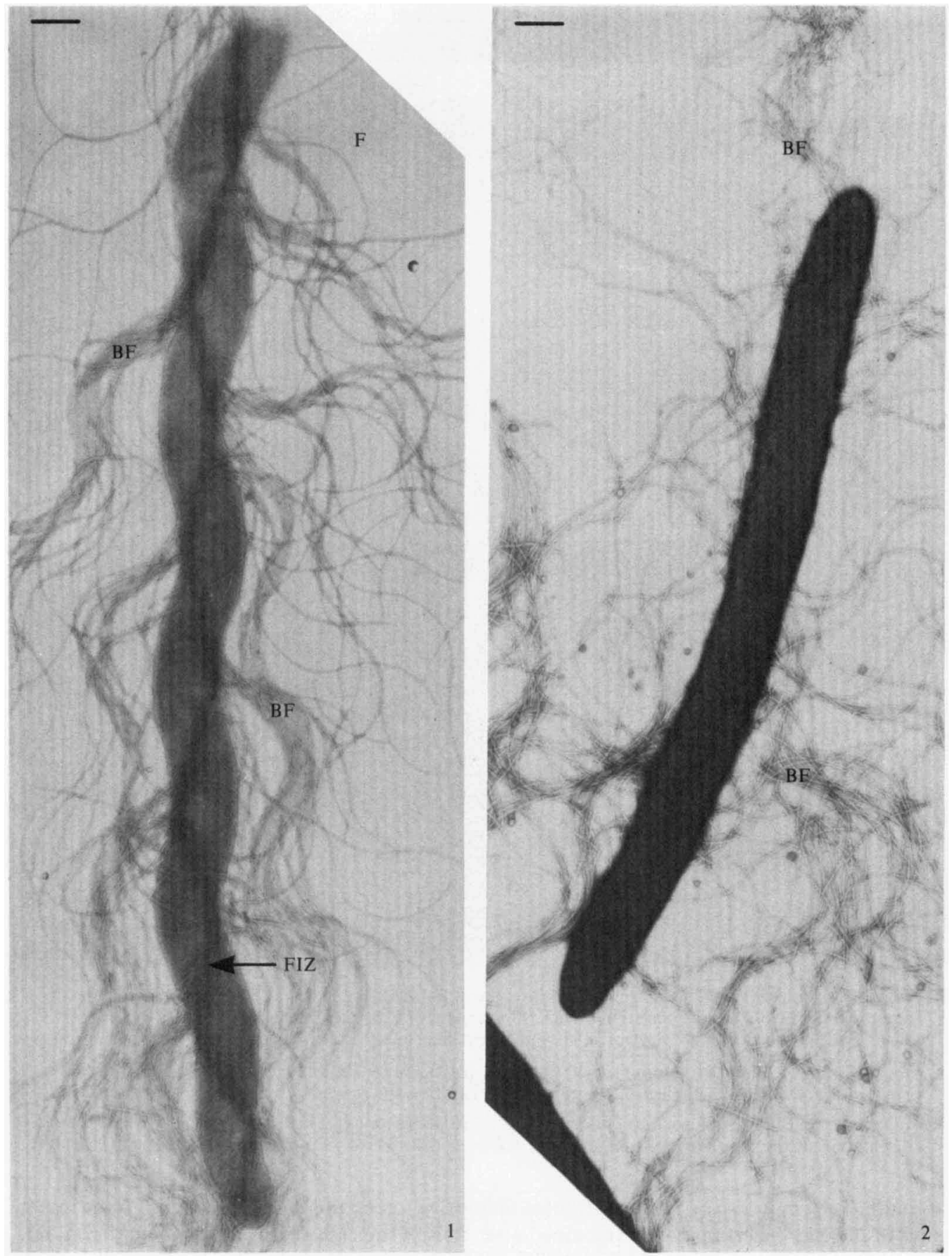

Figs 1-5. The bar markers represent $0.5 \mu \mathrm{m}$ except where indicated. F, flagella; BF, bundles of flagella: FIZ, flagellar insertion zone.

Fig. 1. Strain LL2467 ( $24 \mathrm{~h}$ culture) subjected to $2 \mathrm{~min}$ SDS treatment. Note the distinct, electrondense, flagellar insertion zone and the bundles of flagella located on either side of the cell.

Fig. 2. Strain LL2383 ( $24 \mathrm{~h}$ culture) without detergent treatment. The most striking feature of this bacterium is the arrangement of bundles of flagella. No insertion zone can be seen. 

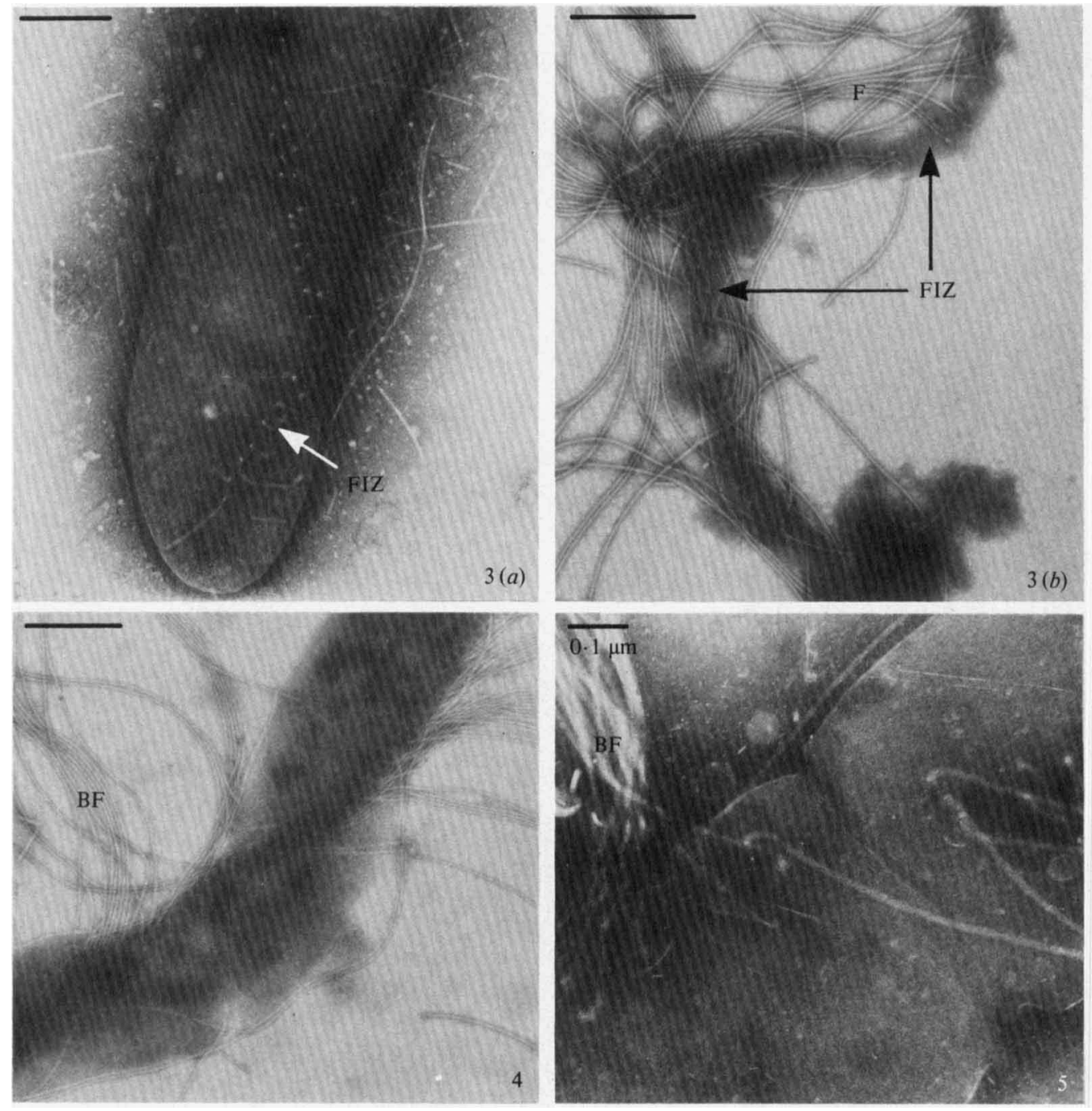

Fig. 3. Strain LL2383 ( $24 \mathrm{~h}$ culture). (a) SDS treatment for $4 \mathrm{~min}$. Most of the flagella are fragmented and broken off close to their insertion points. (b) Remnant of a disintegrated cell after SDS treatment. The flagellar insertion zone remains relatively intact: flagella are still inserted and intact.

Fig. 4. Strain LL2383 (24 h culture) subjected to SDC treatment for $2 \mathrm{~min}$. Flagellar insertion points are not distinct. Patches of an electron-dense material can be seen.

Fig. 5. Strain LL2383 ( $24 \mathrm{~h}$ culture) subjected to $2 \mathrm{~min}$ SDS treatment. The septal region is visible. The orientation of the flagellar insertion zone has not been disturbed by septum formation.

originate. They may also be more resistant to disruptive forces and thereby account for the intact zones of flagellar insertion which remained after lysis of the cells (Fig. $3 \mathrm{~b}$ ). On the other hand, this electron density could also be due to a heavier concentration of stain trapped in this densely flagellate area.

The dimensions of the flagellar insertion zone were similar for each of the isolates, as was the observed helicoidal insertion path around the cell body (Fig. 1). Increases in cell length were accompanied by increases in the number of turns. Periodicity of turn for both the cell and the path of flagella insertions was constant, averaging $2.5 \mu \mathrm{m}$. The electron-dense zone was approximately $180 \mathrm{~nm}$ wide and oriented at an angle of $30^{\circ}$ to the long axis of the cell body. The length of the flagellar insertion region per $360^{\circ}$ turn averaged $2.6 \mu \mathrm{m}$, only slightly larger than its 
wavelength. This is less than the expected value for a helix wrapped around a straight, cylindrical body of similar proportions. We explain this by the fact that the bacterial cell body does not represent a straight cylinder, but a body that is repeatedly curved in an opposite direction from the curvature of the flagellar insertion zone.

The number of flagella per cell was dependent on cell length and ranged from 50 to nearly 300 . An average of 19 flagella were inserted per $1 \mu \mathrm{m}$ length of the electron-dense region.

\section{Effects of cell division and branching}

Cell wall details were not visible in untreated, negatively stained cells (Fig. 2). Selective removal of the outer cell wall layer(s) of dividing cells by SDS treatment revealed the intersection of the septum with the path of flagellation (Fig. 5). A gap of approximately $100 \mathrm{~nm}$ in the insertion path could be noted on either side of the septum. Septum formation did not disrupt the general orientation of the electron-dense insertion zone. Despite the gap in the path of flagellation, the insertion zone continued along its $30^{\circ}$ angled path on either side of the septum, as if flagellum synthesis had been repressed in this region. A model of alternate repression of septum formation and flagellum synthesis was proposed for the selenomonads (Kinglsey \& Hoeniger, 1973). A similar mechanism could be operating here. Assuming that cell growth is accompanied by synthesis of flagella at various points along a lengthening insertion path, repression of flagellum production in the septal region might be expected prior to development of the septum.

The presence of a small number of budding and branched cell forms was observed in older $(48 \mathrm{~h}$ ) broth cultures of each isolate. Budding areas were devoid of flagella (Fig. $6 a$ ) prior to the development of a second arm in branching cells. In a majority of cases the second arm produced its own flagellar insertion region (Figs $6 b, c$ ). However, an occasional branched cell was seen whose second arm was devoid of flagella; only the original flagellar insertion region was present (Fig. $6 d$ ). It may be that a substance or structure is required for flagellum synthesis which has a specific location within the cell. Depending on the site of bud formation, a portion of this structure could be contained within the developing arm. Murray \& Birch-Andersen (1963) believed the polar membrane in Spirillum serpens (Aquaspirillum serpens: Hylemon et al., 1973) to be such a structure; they postulated that it was self-perpetuating or made anew after each division.

In some branched cells, new and old regions of flagellation merged (Fig. $6 c$ ); in others, the new flagellar insertion region terminated some distance from the original path of flagellation (Fig. $6 b$ ). This latter observation, combined with the apparent absence of flagella in some budding regions (Fig. $6 a$ ) suggests that the formation of the new flagellar insertion path does not necessarily arise as an extension or outgrowth of the original path of flagellation, but develops separately at some point on the second arm, distal to the original insertion path. The new insertion path may function as an autonomous unit so that its proximal spread and eventual merger with the original flagellar insertion path may not always occur (Fig. 6b).

\section{Cell motility}

Bacterial flagella are semi-rigid helices which rotate in a clockwise and counterclockwise fashion, driven by a reversible rotary motor at the base of each organelle, the basal body. Several models have been proposed to explain how the basal body gives rise to filament rotation, based on recent evidence which points to proton flux as the energy-generating mechanism (Berg, 1974; Adam, 1977; Lauger, 1977; Macnab, 1979; Manson et al., 1980; Berg et al., 1982). Centipeda periodontii is a multi-flagellated bacterium whose flagella resemble those of other motile bacteria, such as $E$. coli. The method by which flagellar rotation occurs in this organism may be similar to that of $E$. coli and other well-known bacteria. Yet certain aspects of its motility are characteristic of both multi-flagellated bacteria and spirochaetes. Our initial report on $C$. periodontii described a slightly serpentine rod whose motility is accompanied by flexion of the entire cell in a snake-like motion and by rotation around the long axis of the cell body (Lai et al., 1983). This is similar to movements generated by spirochaetes (Weibull, 1960; Berg, 1976). Centipeda periodontii exhibits bundle formation, which is characteristic of peritrichously 

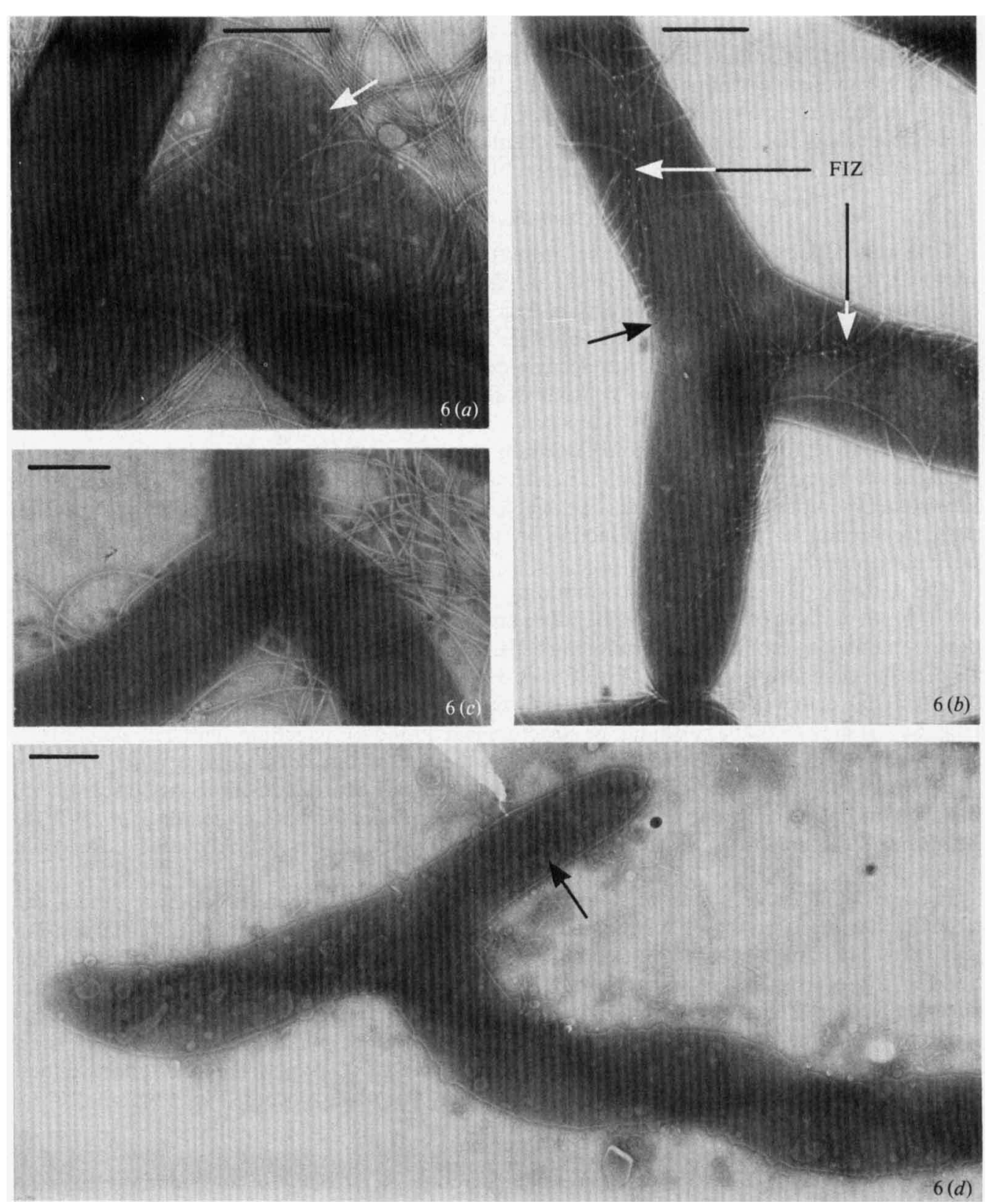

Fig. 6. Branched or budding forms of strain LL2383 ( $48 \mathrm{~h}$ cultures) subjected to SDS treatment for $2 \mathrm{~min}(a-c)$ and $4 \mathrm{~min}(d)$. (a) Portion of a cell with a bud devoid of flagella (arrow). The flagellar insertion zone is visible in the remaining parts of the cell. $(b)$ The uppermost arm of a branched cell contains its own flagellar insertion zone which terminates (short arrow) some distance from the flagellar insertion zone of the remaining parts of the cell. $(c)$ Merged zones of flagellar insertion in a branching cell. $(d)$ Branched cell with one 'arm' of the cell totally devoid of flagella (arrow). The bar markers represent $0.5 \mu \mathrm{m}$. FIZ, flagellar insertion zone.

flagellated bacteria (Fig. 1). This is a prominent feature of the organism when viewed by darkfield microscopy (hence its name, Centipeda: Lai et al., 1983). This indicates that similar hydrodynamic forces are present during cell movement which contribute to bundle formation (Anderson, 1975; Macnab, 1977). 
The development of a second arm in branching cells noticeably affected cell movements. Rotation of the cell about its long axis was greatly impeded by the added appendage. Cell movements were often limited to snake-like motions (unpublished observations).

To our knowledge this is the first reported example of a helically flagellated bacterium. These organisms represent a new class of motile bacteria, which we designate as helicotrichous (Gk $\mathbf{n}$. helix, helix + Gk n. thrix, hair): a helical distribution of flagella around the cell body.

This project was supported by NIDR grants DE-02623 and DE-04759. Drs Males and Berthold were supported by NIDR training grant 5T-32-DE-07085. Parts of this project were presented at the annual session of the American Association for Dental Research, 1983.

\section{REFERENCES}

ADAM, G. (1977). Rotation of bacterial flagella as driven by cytomembrane streaming. Journal of Theoretical Biology 65, 713-726.

ANDERSON, R. A. (1975). Formation of the bacterial flagellar bundle. In Swimming and Flying in Nature, vol. I, pp. 45-56. Edited by T. Y. T. Wu, C. J. Brokaw \& C. Brennen. New York: Plenum Press.

BAYER, M. E. \& ANDERSON, T. F. (1965). The surface structure of Escherichia coli. Proceedings of the National Academy of Sciences of the United States of America 54, 1592-1599.

BERG, H. C. (1974). Dynamic properties of bacterial flagellar motors. Nature, London 249, 77-79.

BERG, H. C. (1976). How spirochetes may swim. Journal of Theoretical Biology 56, 269-273.

Berg, H. C., Manson, M. D. \& Conley, M. P. (1982). Dynamics and energetics of flagellar rotation in bacteria. Symposia of the Society for Experimental Biology 35, 1-31

COHEN-BAzIRE, G. \& LONDON, J. (1967). Basal organelles of bacterial flagella. Journal of Bacteriology 94. 458-465.

Coulton, J. W. \& Murray, R. G. E. (1978). Cell envelope associations of Aquaspirillum serpens flagella. Journal of Bacteriolog. 136, 1037-1049.

DePamphilis, M. L. \& Adler, J. $(197 / a)$. Fine structure and isolation of the hook basal body complex of flagella from Escherichia coli and Bacillus subtilis. Journal of Bacteriology 105, 384-395.

DePamphilis, M. L. \& AdLER, J. (197|b). Attachment of flagellar basal bodies to the cell envelope: specific attachment to the outer, lipopolysaccharide mem. brane and the cytoplasmic membrane. Journal of Bacteriology 105, 396-407.

HILL. M. J. (1967). Action of bile salts on bacterial cell walls. Nature, London 214. 1152-1154.

Holdeman, L. V., Cato, E. P. \& Moore, W. E. C. (editors) (1977). Anaerobe Lahoratory Manual, 4th edn, p. 144. Blacksburg: Virginia Polytechnic Institute Anaerobe Laboratory.

Hougen, K. H. \& BirCh-ANdersen, A. (1971). Electron microscopy of endoflagella and microtubules in Treponema Reiter. Acta pathologica et microbiologica scandinavica, Section $B$ 79, 37-50.

Hylemon, P. B., Wells, J. S., JR, KRIEG, N. R. \& JaNNASCH, H. W. (1973). The genus Spirillum: a taxonomic study. International Journal of $S_{1}$ stematic Bacteriology 23, 340-380.

Kingsley, V. V. \& Hoeniger, J. F. M. (1973). Growth, structure and classification of Selenomonas. Bacteriological Reviews 37, 479-521.
Lai, C.-H., Dougherty, P. \& Listgarten, M. A. (1981a). Partial characterization of unidentified gram-negative, anaerobic, motile rods from periodontitis lesions. Journal of Dental Research 60, 331.

Lai, C.-H., Listgarten, M. A., Tanner, A. C. R. \& SOCRANSKY, S. S. $(1981 b)$. Ultrastructures of Bacteroides gracilis, Campylobacter concisus, Wolinella recta, and Eikenella corrodens, all from humans with periodontal disease. International Journal of Systematic Bacteriology 31, 465-475.

LaI, C.-H., Males, B. M., Dougherty, P. A., Berthold, P. \& Listgarten, M. A. (1983). Centipeda periodontii, gen. nov., sp. nov., from human periodontal lesions. International Journal of Sistematic Bacteriology 33, 628-635.

LAUGER, P. (1977). Ion transport and rotation of bacterial flagella. Nature, London 268, 360-362.

LeE, S. Y., Mabee, M. S. \& Jangaard, N. O. (1978). Pectinatus, a new genus of the family Bacteroidaceae. International Journal of Systematic Bacteriology 28, $582-594$

MaCnaB, R. M. (1977). Bacterial flagella rotating in bundles: a study in helical geometry. Proceedings of the National Academy of Sciences of the United States of America 74, 221-225.

Macnab, R. M. (1979). How do flagella propel bacteria? Trends in Biomedical Science 4, N1013.

Manson, M. D., Tedesco, P. M. \& Berg, H. C. (1980). Energetics of flagellar rotation in bacteria. Journal of Molecular Biology 138, 541-561.

Murray, R. G. E. \& Birch-Andersen, A. (1963). Specialized structure in the region of the flagella tuft in Spirillum serpens. Canadian Journal of Microbiology. 9. 393-401.

Remsen, C. C., Watson, S. W., Waterbury, J. B. \& TRUPER, H. G. (1968). Fine structure of Ectothiorhodospira mobilis Pelsh. Journal of Bacteriology 95 , 2374-2392.

Ritchie, A. E., Keeler, R. F. \& Bryner, J. H. (1966). Anatomical features of Vibrio fetus: electron microscopic survey. Journal of General Microbiology 43, 427-438.

VAITUZIS, Z. \& DoetsCH, R. N. (1969). Relationship between cell wall. cytoplasmic membrane, and bacterial motility. Journal of Bacteriolog! 100, 512 521 .

Weibull, C. (1960). Movement. In The Bacteria, pp. 153-205. Edited by I. C. Gunsalus \& R. Y. Stanier. New York: Academic Press. 